\title{
MORTALITAS DAN RESORPSI FETUS MENCIT (Mus musculus L.) SETELAH PEMBERIAN EKSTRAK ETANOL TANAMAN SURUHAN (Peperomia pellucida (L.,) Kunth.)
}

\author{
Hendri Busman $^{1)}$, Nuning Nurcahyani ${ }^{2)}$, Yosi Dwi Saputra ${ }^{3)}$, Salman Farisi ${ }^{4)}$, \\ Qotrunnada Salsabila ${ }^{5}$ \\ 1,2,3,4,5 Universitas Lampung \\ Email : nadasalsa2112@gmail.com
}

\begin{abstract}
ABSTRAK
Tanaman Suruhan (Peperomia pellucida (L.,) Kunth.) merupakan tanaman obat yang memiliki senyawa metabolit sekunder seperti alkaloid, flavonoid, saponin, tanin, dan steroid. Berbagai senyawa kimia tersebut yang berpotensi sebagai obat tetapi perlu diperhatikan kemungkinan adanya efek samping terhadap organisme khususnya pada masa kehamilan. Penelitian ini bertujuan menguji efek teratogenik ekstrak tanaman suruhan terhadap fetus mencit (Mus musculus L.), meliputi mortalitas dan resorpsi. Penelitian ini menggunakan metode Rancangan Acak Lengkap (RAL) yang terdiri dari 4 perlakuan dengan 20 ekor mencit betina dibagi ke dalam 4 kelompok yaitu: $\mathrm{K}(+)$ (Aquabides), P1 diberi ekstrak tanaman suruhan dengan dosis $(1,68 \mathrm{mg} / \mathrm{g} \mathrm{bb}), \mathrm{P} 2$ (3,36 $\mathrm{mg} / \mathrm{g} \mathrm{bb})$, dan P3 $(6,72 \mathrm{mg} / \mathrm{g} \mathrm{bb})$. Hasil penelitian terhadap persentase fetus yang mengalami mortalitas dan resorpsi fetus antara kontrol $\mathrm{K}(+)$ dan perlakuan dengan ekstrak etanol suruhan ( $\mathrm{P} 1, \mathrm{P} 2$, dan $\mathrm{P} 3)$ tidak menunjukkan perbedaan yang bermakna secara statistik berdasarkan uji ANOVA satu faktor ( $\mathrm{p}$ value 0,418 ). Hasil penelitian yang didapat menunjukkan bahwa ekstrak etanol tanaman suruhan tidak menyebabkan mortalitas pada fetus mencit, namun menyebabkan resorpsi pada fetus mencit pada pemberian dosis sebesar 1,62 $\mathrm{mg} / \mathrm{g} \mathrm{BB}, 3,36 \mathrm{mg} / \mathrm{g} \mathrm{BB}$, dan $6,72 \mathrm{mg} / \mathrm{g} \mathrm{BB}$.
\end{abstract}

Kata kunci: fetus; mencit; mortalitas; resorpsi; suruhan

\begin{abstract}
Pepper elder (Peperomia pellucida (L.,) Kunth.) is a medicinal plant that has secondary metabolites such as alkaloids, flavonoids, saponins, tannins, and steroids. The side effects for organisms of those chemical compounds, which are potentially beneficial for their medicinal use, still need to be considered especially in pregnancy. This study aims to determine the teratogenic effects of pepper elder extract on mortality and resorption of mice (Mus musculus L.) fetus. This study uses total random sampling design with 4 treatments consisting of 20 female mice divided into 4 groups: the control group $(K(+))$ which is given Aqua distillation and the treatment groups which are all given the pepper elder extract with different doses, where the first treatment group $(P 1)$ is given $1.68 \mathrm{mg} / \mathrm{g}$ body weight of the extract, the second treatment group (P2) is given $3.36 \mathrm{mg} / \mathrm{g}$ body weight of the extract, and the third treatment group (P3) is given $6.72 \mathrm{mg} / \mathrm{g}$ body weight of the extract. The results obtained of mortality and resorption percentage of mice fetus between the control group $(K(+))$ and the treatment groups $(P 1, P 2$, and P3) showed that there is no statistically meaningful difference based on one-way ANOVA test ( $p$ value 0,418). This study showed that ethanol extract of pepper elder causes no mortality in mice fetus, yet it causes resorption on mice fetus at given doses of $1,62 \mathrm{mg} / \mathrm{g}$ body weight, $3,36 \mathrm{mg} / \mathrm{g}$ body weight, dan $6,72 \mathrm{mg} / \mathrm{g}$ body weight.
\end{abstract}

Keywords: fetus; mice; mortality; pepper elder; resorption

\section{PENDAHULUAN}

Indonesia merupakan negara
besar yang terkenal karena keanekaragaman obat tradisional yang menggunakan bahan - bahan alami dari tumbuhan. Tanaman obat 
sejak zaman dahulu sudah dipergunakan untuk meningkatkan maupun memulihkan kesehatan, pencegahan penyakit dan penyembuhan oleh masyarakat Indonesia. Tanaman suruhan merupakan suatu tanaman herbal yang berasal dari Amerika Selatan tetapi pada umumnya banyak ditemukan di Asia Tenggara (Arrigoni-Blank et al., 2002).

Menurut Dalimarta (2006), tanaman suruhan banyak digunakan masyarakat untuk mengobati beberapa penyakit seperti radang, sakit perut, hipoglikemik (Sheikh et al., 2013), demam, bisul, asam urat, kolesterol, anti bakteria (Xu et al., 2006), anti kanker (Wei et al., 2011), dan mengobati penyakit ginjal (Majumder, Abraham, dan V, 2011).

Pada tanaman suruhan terdapat beberapa senyawa toksik yaitu senyawa alkaloid, kardenolit, flavonoid, saponin, tanin (Egwuche, Odetola, dan Erukainure, 2011; Angelina et al., 2015) yang diduga mempunyai sifat sitotoksik, yang dapat menghambat pertumbuhan dan perkembangan sel, salah satunya adalah perkembangan fetus mencit.

Selain itu efek samping tanaman suruhan sebagai obat belum diketahui secara ilmiah bagi ibu yang sedang hamil. Oleh karena itu perlu dilakukan penelitian lebih lanjut tentang tingkat keamanan pemakaian dengan memberikan ekstrak tanaman suruhan untuk melihat ada atau tidaknya kelainan pada fetus hewan uji akibat pemberian ekstrak tanaman suruhan selama periode organogenesis.

Penggunaan tanaman sebagai obat harus memiliki persyaratan aman, bermanfaat dan telah terstandar. Untuk dapat memenuhi persyaratan tersebut perlu dilakukan upaya penegasan keamanan melalui uji toksisitas. Tujuan penelitian ini untuk mengetahui pengaruh teratogenik dari ekstrak tanaman suruhan terhadap mortalitas dan resorpsi.

\section{METODE PENELITIAN}

Penelitian menggunakan uji eksperimental dengan desain rancangan acak lengkap. Penelitian dilaksanakan pada bulan SeptemberNovember 2019 yang bertempat di Jurusan Biologi FMIPA Universitas Lampung, yaitu untuk proses pemeliharaan dan perlakuan hewan uji di Laboratorium Zoologi sedangkan untuk pembuatan ekstrak tanaman suruhan di Laboratorium Botani.

Tahap awal penelitian yaitu melakukan aklimatisasi pada hewan uji (mencit) selama 1 minggu di dalam kandang yang telah disiapkan. Setiap kendang didalamnya terdapat 2 ekor mencit jantan dan 5 ekor mencit betina, mangkok berisi pakan, sekam padi dan tempat minum, dengan ukuran kendang $100 \mathrm{~cm}$ x 50 $\mathrm{cm}$. Mencit diberi pakan pur ayam kecil dan minum berupa air PAM setiap harinya. Setiap 2 hari sekali sekam diganti untuk menghindari kondisi lembab akibat tumpahan pakan maupun minum mencit dan mencegah timbulnya pertumbuhan bakteri atau jamur.

Proses pembuatan ekstrak tanaman suruhan meliputi tanaman suruhan dibersihkan lalu dikeringkan menggunakan oven dengan suhu $70^{\circ} \mathrm{C}$ selama 15 menit, setelah kering dilakukan proses penggilingan dengan menggunakan blender hingga menjadi bubuk didapatkan hasil 283,9 g. Bubuk tanaman suruhan dimasukkan kedalam Beaker glass berukuran $2000 \mathrm{ml}$ lalu dimaserasi dengan menggunakan pelarut etanol 96\% selama $3 \times 24$ jam hingga diperoleh maserat. Filtrat yang telah didapatkan akan dipekatkan dengan menggunakan alat rotary evaporator pada suhu $50^{\circ} \mathrm{C}$ selama 1 jam (Busman, 2013).

Proses pemberian perlakuan pada mencit dengan pemberian ekstrak tanaman suruhan sesuai dengan unit perlakuan yang telah ditentukan. Mencit 20 ekor yang berumur $2-3$ bulan dibagi menjadi 4 kelompok, 
kelompok $\mathrm{K}(+)$ sebagai kontrol positif yang hanya diberikan aquabides saja, sedangkan P1 adalah kelompok perlakuan dengan pemberian ekstrak tanaman suruhan dengan dosis $1,68 \mathrm{mg} / \mathrm{g}$ BB, $\mathrm{P} 2$ : $3,36 \mathrm{mg} / \mathrm{g} \mathrm{BB}$, dan $\mathrm{P} 3: 6,72 \mathrm{mg} / \mathrm{g}$ BB. Mencit yang telah hamil atau bunting pada hari ke-6 selanjutnya dilakukan intervensi dengan pemberian ekstrak tanaman suruhan selama 12 hari, yang dimulai pada hari ke-6 sampai hari ke-17 dan dilakukan secara berulang (Dzulfikor, Akbar, dan Susilo, 2015).

Tahap selanjutnya adalah melakukan laparatomi pada mencit yang dilakukan pada hari ke-18 kehamilan. Proses pembiusan dengan menggunakan cairan kloroform selanjutnya mencit ditimbang menggunakan timbangan analitik, setelah itu dilakukan proses pembedahan atau laparatomi untuk mengeluarkan fetus dengan cara memotong uterus dan plasenta kemudian dilakukan pengamatan. Penghitungan fetus hidup maupun mati serta mengamati ada atau tidak adanya resorpsi ataupun kelainan secara visual (Wilson, 1973).

Penelitian ini telah mendapatkan persetujuan etik (ethical approval) dengan nomor surat 3778/UN26.18/ PP.05.02 PP/2019.

Parameter penelitian meliputi:

a. Mortalitas Fetus Mati Pada Mencit

Betina

Pengamatan dilakukan dengan cara mencit dibedah, setelah dibedah dapat terlihat uterus diangkat dan ditimbang bersama-sama embrio yang di dalamnya. Uterus selanjutnya dimasukkan ke dalam cairan fisiologis yaitu larutan $\mathrm{NaCl} 0,9 \%$. Fetus yang berkembang penuh dan merespon sentuhan di kategorikan sebagai fetus hidup, fetus yang berkembang penuh tetapi tidak merespon sentuhan dikategorikan sebagai fetus mati. Jumlah fetus hidup dan fetus mati tersebut kemudian dihitung (Harlis, Malik, dan Nufrianti, 2018). b. Resorpsi fetus pada mencit betina

Pengamatan dapat dilakukan dengan cara pembedahan mencit yang telah hamil hingga 18 hari. Selanjutnya mencit dibedah, fetus yang telah dikeluarkan dari uterus dan telah dibersihkan dengan larutan $\mathrm{NaCl}$, dapat dilakukan proses menghitung jumlah kejadian resorpsi fetus dari setiap ekor mencit pada kelompok perlakuan. Pada tiap ekor mencit dihitung jumlah kelahiran fetus normal maupun jumlah resorpsi (fetus abnormal dengan bentuk seperti gumpalan), setelah itu diinterprestasikan dalam bentuk angka (Rubiyati, 2016).

Pada penelitian ini data mortalitas dan resorpsi dianalisis dengan menggunakan metode statistik One-Way ANOVA (Analysis of Variance) pada taraf 5\% menggunakan program software SPSS. Apabila hasil ANOVA signifikan, maka dilakukan uji lanjut BNT (Beda Nyata Terkecil) pada taraf nyata $5 \%$ menggunakan program software Minitab versi 16.0 untuk dapat mengetahui adanya perbedaan nyata perbandingan antara $\mathrm{K}(+)$ pemberian aquabides sebagai kontrol normal, pemberian ekstrak etanol suruhan 1,68 $\mathrm{mg} / \mathrm{g}$ BB pada (P1), pemberian ekstrak etanol suruhan $3,36 \mathrm{mg} / \mathrm{g}$ BB pada (P2), dan pemberian ekstrak etanol suruhan 6,72 mg/g BB pada (P3). Hasil penelitian yang berupa anatomi tulang belakang fetus dianalisis secara deskripsi.

\section{HASIL DAN PEMBAHASAN}

Berdasarkan hasil penelitian yang telah dilakukan mengenai pemberian ekstrak etanol suruhan terhadap mortalitas dan resorpsi fetus mencit dapat tersaji seperti berikut ini.

\section{a. Hasil Uji Fitokimia Ekstrak Etanol Suruhan \\ Berdasarkan hasil uji fitokimia ekstrak etanol suruhan dapat disajikan dalam Tabel 1 berikut.}

Tabel 1. Hasil uji fitokimia ekstrak etanol suruhan. 


\begin{tabular}{cc}
\hline Uraian & Hasil Uji \\
\hline Saponin & + \\
Steroid/Terpenoid & + \\
Tanin & + \\
Alkaloid & + \\
Flavonoid & + \\
\hline
\end{tabular}

Keterangan :

(+) : Ada, (-) : Tidak Ada

Berdasarkan data pada Tabel 1 dapat diketahui bahwa ekstrak etanol suruhan mengandung senyawa metabolit sekunder seperti saponin, steroid/terpenoid, tanin, alkaloid, dan flavonoid.

b. Rerata Mortalitas Fetus Mencit

Pengaruh pemberian ekstrak etanol suruhan terhadap mortalitas fetus mencit. dapat dilihat pada Tabel 2.

Tabel 2. Rerata persentase fetus mati mencit setelah pemberian ekstrak tanaman suruhan.

\begin{tabular}{cc}
\hline \multirow{2}{*}{ Perlakuan } & Mortalitas Fetus Mencit \\
\cline { 2 - 2 } & $\mathrm{X} \pm \mathrm{SE}$ \\
\hline $\mathrm{K}(+)$ & $0,00 \pm 0,000$ \\
(P1) & $0,20 \pm 0,200$ \\
(P2) & $0,00 \pm 0,000$ \\
(P3) & $0,00 \pm 0,000$ \\
\hline
\end{tabular}

Keterangan :

$\mathrm{K}(+)=$ Kontrol

$\mathrm{P} 1=$ Perlakuan ekstrak etanol tanaman suruhan $1,68 \mathrm{mg} / \mathrm{g}$ $\mathrm{BB}$

$\mathrm{P} 2=$ Perlakuan ekstrak etanol tanaman suruhan $3,36 \mathrm{mg} / \mathrm{g}$ BB

P3 = Perlakuan ekstrak etanol tanaman suruhan $6,72 \mathrm{mg} / \mathrm{g} \mathrm{BB}$

$\mathrm{SE}=$ Std. Error

Berdasarkan data pada Tabel 2, dapat diketahui bahwa fetus dari kelompok $\mathrm{K}(+) 100 \%$ hidup. Pada kelompok yang diberikan ekstrak etanol suruhan fetus hidup cenderung berkurang (lebih kecil $100 \%$ ) pada dosis rendah. Hasil uji ANOVA, didapatkan bahwa dari setiap kelompok perlakuan tidak berbeda nyata ( $\mathrm{p}$ value $>\alpha$ )
Setelah dilakukan analisis statistik terhadap persentase kematian didapatkan bahwa fetus dari setiap kelompok kontrol, dosis $3,36 \mathrm{mg} / \mathrm{g} / \mathrm{BB}$, dan $6,72 \mathrm{mg} / \mathrm{g} / \mathrm{BB}$ ekstrak tanaman suruhan $100 \%$ hidup. pada penelitian ini didapatkan hasil yang signifikan 0,418 yang menunjukkan tidak adanya perbedaan yang nyata antara kelompok perlakuan ( $\mathrm{p}$ value $>\alpha$ ), meskipun tidak signifikan tetapi ekstrak tanaman suruhan mempunyai kecenderungan bersifat embriotoksik (Bailey, Knight, dan Balcombe, 2005).

Perlakuan yang telah diberikan tidak menyebabkan fetus mengalami mortalitas. Fetus yang lahir hidup menunjukkan fetus masih dapat mentolerir senyawa asing yang terkandung di dalam tanaman suruhan. Sel-sel tubuh fetus bersifat reversibel yaitu dapat mengganti sel-sel yang rusak atau mati sehingga fetus masih dapat bertahan hidup (Widyastuti, 2006).

Fetus mati diduga disebabkan karena kematian sel pada tahap akhir poliferasi maka dari itu hanya sebagian sel yang dapat diperbaiki dan pada saat pembedahan proses resorbsi oleh induk belum sempurna sehingga biasanya fetus yang mati ditemukan dalam keadaan cacat. Kematian intrauterin seperti resorpsi dan fetus mati kemungkinan dapat pula disebabkan oleh adanya kontraksi otot uterus selama masa organogenesis akibat pemberian ekstrak suruhan. Senyawa aktif seperti alkaloid, saponin dan polifenol yang terkandung di dalam ekstrak suruhan dimungkinkan dapat memacu kontraksi otot polos uterus, adanya kontraksi otot polos uterus pada masa kebuntingan dapat menyebabkan gangguan pada janin (Sumastuti, 2009). Hal ini sesuai dengan hasil penelitian Muna (2010), menunjukkan kematian fetus dapat terjadi akibat ketidakmampuan perbaikan (recovery) untuk menggantikan sel yang rusak dengan sel normal.

Proses pertumbuhan dan perkembangan fetus membutuhkan asupan nutrisi berupa asam amino, vitamin, dan mineral dari induk ke fetus. 
Suruhan juga mengandung beberapa zat yang diperlukan oleh tubuh seperti serat, protein, karbohidrat, dan lemak (Egwuche, Odetola, dan Erukainure, 2011). Dengan demikian ekstrak suruhan yang mengandung cukup tinggi protein dapat dihidrolisis oleh enzim bromelin menjadi molekul yang lebih sederhana sehingga lebih mudah dicerna oleh induk tikus selama kehamilan. Hal ini diduga menyebabkan tidak adanya kematian fetus karena nutrisi yang terkandung dalam pakan dapat terserap lebih baik oleh induk mencit yang sedang bunting (Bahde et al., 2007).

\section{c. Rerata Resorpsi Fetus}

Pengaruh pemberian ekstrak etanol suruhan terhadap resorpsi fetus mencit (Mus musculus L.) dapat dilihat pada Tabel 3.

Tabel 3. Rerata persentase embrio resorpsi mencit setelah pemberian ekstrak tanaman suruhan.

\begin{tabular}{cc}
\hline \multirow{2}{*}{ Perlakuan } & $\begin{array}{c}\text { Resorpsi Fetus } \\
\text { Mencit }\end{array}$ \\
\cline { 2 - 2 } & $\mathrm{X} \pm \mathrm{SE}$ \\
\hline $\mathrm{K}(+)$ & $0,00 \pm 0,000$ \\
(P1) & $0,20 \pm 0,200$ \\
(P2) & $0,40 \pm 0,245$ \\
(P3) & $0,60 \pm 0,400$ \\
\hline
\end{tabular}

Keterangan :

$\mathrm{K}(+)=$ Kontrol

$\mathrm{P} 1$ = Perlakuan ekstrak etanol tanaman suruhan $1,68 \mathrm{mg} / \mathrm{g}$ BB

$\mathrm{P} 2$ = Perlakuan ekstrak etanol tanaman suruhan $3,36 \mathrm{mg} / \mathrm{g} \mathrm{BB}$

P3 = Perlakuan ekstrak etanol tanaman suruhan $6,72 \mathrm{mg} / \mathrm{g} \mathrm{BB}$

$\mathrm{SE}=$ Std. Error

Berdasarkan data pada Tabel 3, dapat diketahui bahwa embrio resorpsi dapat ditemukan pada semua kelompok perlakuan kecuali kontrol. Ekstrak tanaman suruhan memberikan pengaruh terhadap persentase resorpsi mencit pada tahap kehamilan praimplantasi. Menurut Lu (1995), resorpsi embrio adalah suatu kematian embrio sejak awal proses pembentukan yang dapat ditunjukkan dengan adanya sisa jaringan embrio dalam uterus yang berupa gumpalan merah. Hal tersebut sesuai dengan teori (A, Almunawwarah, dan Fitria, 2013), senyawa yang bersifat teratogen jika diberikan pada kehamilan mencit tahap praimplantasi tidak menyebabkan cacat morfologi, abortus atau embrio yang diresobsi oleh tubuh induk mengakibatkan kelainan fungsional yang tidak dapat dideteksi setelah kelahiran.

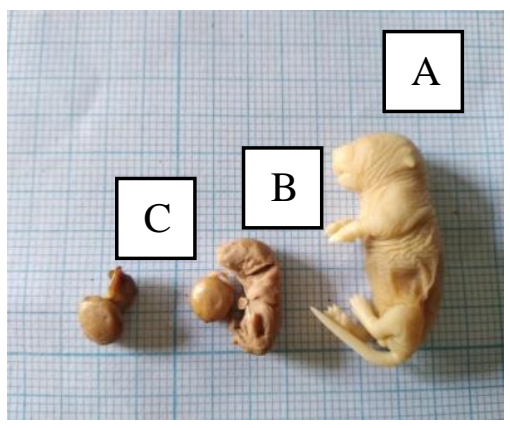

Gambar 1. Morfologi fetus mencit setelah pemberian ekstrak etanol tanaman suruhan: A. Fetus normal (kanan), B. Fetus mati di dalam kandungan, C. Fetus resorpsi (skala satu kotak pada kertas millimeter berukuran $1 \mathrm{~mm}^{2}$ ).

Berdasarkan penelitian terkait pengaruh suruhan terhadap resorpsi fetus, hasilnya menunjukkan bahwa suruhan menyebabkan resorpsi karena efek sitotoksik yang menghambat perkembangan embrio. Semakin tinggi tingkat dosis suruhan yang diberikan kepada mencit, semakin tinggi pula efek sitotoksik terhadap embrio terbukti pada dosis rendah mengakibatkan fetus resorpsi (Goldstein, Aronow, dan Kalman, 1974). Efek suruhan menyebabkan embrio gagal membelah dan berkembang sehingga embrio yang dihasilkan mengalami resorpsi. Resorpsi fetus merupakan salah satu agen yang bersifat teratogenik (Harbinson, 1980). Hasil uji fitokimia yang telah dilakukan menunjukkan bahwa senyawa alkaloid yang merupakan senyawa metabolit sekunder yang bersifat basa dan dapat menyebabkan penyakit jantung, kanker paru-paru, tekanan darah tinggi, dan 
gangguan terhadap kehamilan maupun janin (Wink, 2008).

Alkaloid merupakan zat aktif yang bersifat racun, bisa menimbulkan rasa pahit dan sedikit berbahaya dalam penggunaannya. Karena alkaloid dapat menghambat proses terjadinya ovulasi dan meresorpsi fetus tikus sehingga apabila diberikan pada masa kehamilan, zat aktif ini bisa mengurangi jumlah fetus yang ada di dalam uterus tikus maupun mencit (Burow et al., 2001; Limbong, 2003; Widyastuti, 2006; Garor et al., 2009). Selain itu senyawa saponin juga diduga mampu mengakibatkan gangguan sekresi GnRH yang kemudian akan berpengaruh terhadap pembentukan, perkembangan, dan pematangan folikel. Selain itu senyawa saponin mempunyai pengaruh negatif terhadap reproduksi ternak seperti aborsi atau kematian, yang menyebabkan steril dan penghentian proses kebuntingan. Saponin berperan besar dalam pengeluaran hormon luteinizing. Senyawa ini secara langsung menghambat kerja gen yang bertanggung jawab dalam proses steroidogenesis dan menekan perkembangan sel granula yang diatur oleh hormon perangsang folikel dalam ovarium (Francis et al., 2002).

Lambatnya pertumbuhan pada fetus diduga adanya faktor kerentanan genetik (kepekaan) dari fetus tersebut sebagai individu terhadap senyawa yang terkandung pada tanaman suruhan. Adanya resorpsi berupa gumpalan merah yang tertanam pada uterus disebabkan pengaruh pemberian ekstrak etanol suruhan pada masa organogenesis bila terjadi pemaparan suatu senyawa yang dapat merusak sel pada masa ini, maka sel tidak bisa berkembang menyebabkan fetus mati (A, Almunawwarah, dan Fitria, 2013). Jumlah fetus yang mengalami resorpsi semakin besar seiring dengan meningkatnya dosis ekstrak tanaman suruhan yang diberikan, maka dari itu resorpsi fetus merupakan suatu indikasi agen teratogenik (Santoso, 2006).

Teratologi adalah suatu ilmu yang mempelajari tentang efek toksik terhadap malformasi atau cacat pada embrio. Teratologi dapat terdiri dari kondisi, mekanisme, wujud, dan sifat efek racun. Proses perpindahan racun di dalam tubuh meliputi absorpsi, distribusi, dan metabolisme (Harbinson, 2001).

Absorpsi racun dapat melintasi membran dan masuk ke dalam sirkulasi darah, serta dapat terjadi melalui kulit maupun paru, serta saluran cerna. Absorpsi racun dapat melaui mekanisme fagositosis, dan pinositosis (Kertia et al., 2005). Distribusi merupakan suatu proses yang dapat menghantarkan racun sampai ke tempat tertentu di dalam tubuh. Tempat distribusi ini dapat berupa jaringan, organ maupun tulang. Faktor penting dari distribusi yang dapat mempengaruhi keefektifan distribusi racun yaitu ikatan protein dan kecepatan aliran darah. Metabolisme atau suatu perubahan hayati racun menjadi suatu zat metabolit yang secara kimia berbeda dengan zat kimia induk, terutama terjadi dalam organ hati. Keefektifan suatu senyawa metabolisme racun dan ketoksikan dapat dipengaruhi oleh aneka ragam faktor seperti intrinsik, xenobiotik, fisiologi maupun lingkungan. Sifat metabolit xenobiotika yang terbentuk dapat mengakibatkan menurunkan ataupun menaikan ketoksikan racun (Kertia et al., 2005).

Evaluasi dari suatu efek teratogen mempunyai beberapa kategori diantaranya adalah aberasi, resorpsi, dan toksisitas janin. Aberasi merupakan cacat morfologi yang meliputi struktur luar ataupun dalam. Selain itu, mugkin terdapat kelainan fungsional. Contohnya, timbulnya tulang rusuk tambahan dan kelainan pada penulangan sternum mungkin efeknya sedikit ataupun tidak nampak dari morfologi luar, aktivitas fungsional, ataupun kelangsungan hidup janin ( $\mathrm{Lu}, 1995)$. Toksisitas pada janin dapat dilihat dari berkurangnya berat badan janin yang tidak bertahan hidup. Oleh sebab itu data ini sering digunakan sebagai acuan atau kriteria dalam menilai teratogenitas toksikan tersebut (Lu, 1995). 
Pada penelitian ini didapatkan bahwa peningkatan dosis ekstrak tanaman suruhan cenderung diikuti dengan menurunnya jumlah fetus hidup. Namun setelah dilakukannya analisis statistik dengan menggunakan ANOVA terhadap persentase embrio resorpsi didapatkan hasil signifikan 0,418 yang artinya tidak adanya perbedaan yang nyata dari setiap kelompok perlakuan ( $\mathrm{p}$ value $>\alpha$ ). Meskipun tidak signifikan tetapi ekstrak tanaman suruhan mempunyai kecenderungan bersifat embriotoksik maupun embrio letal.

\section{KESIMPULAN}

Dari hasil penelitian yang telah dilakukan dapat disimpulkan bahwa pemberian ekstrak etanol tanaman suruhan pada induk mencit:
a. Tanaman suruhan tidak menyebabkan mortalitas pada fetus mencit.
b. Tanaman suruhan pada dosis 1,62 $\mathrm{mg} / \mathrm{g} \mathrm{BB}, 3,36 \mathrm{mg} / \mathrm{g} \mathrm{BB}$, dan 6,72 $\mathrm{mg} / \mathrm{g}$ BB menyebabkan resorpsi pada fetus mencit.

\section{SARAN}

Adapun saran yang disampaikan dari penelitian ini yaitu perlu adanya uji lanjut terhadap morfologi fetus yang meliputi kelainan ginjal, hati, kardiovaskuler, maupun sistem rangka untuk memaksimalkan kemungkinan kecacatan yang terjadi sebagai panduan untuk ibu hamil.

\section{REFERENSI}

A, A., Almunawwarah, N. A. and Fitria, N. (2013) 'Uji Efek Teratogen Kakao Bubuk pada Fetus Mencit Putih', Indonesian Journal of Pharmaceutical Science and Technology, 11(1), pp. 9-26.

Angelina, M. et al. (2015) 'Karakteristik Ekstrak Etanol Herba Ketumpangan Air (Peperomia pellucid L. Kunth)', Biopropal Industri, 6(2), pp. 53-61.

Arrigoni-Blank, M. de F. et al. (2002) 'Seed Germination, phenology, and antiedematogenic activity of Peperomia pellucida (L.) H.B.K.', BMC Pharmacology, 2(12), pp. 1-8. doi: https://doi.org/10.1186/14712210-2-12.

Bahde, R. et al. (2007) 'Bromelain Ameliorates Hepatic Microcirculation after Warm Ischemia', Journal of Surgical Research, 139(1), pp. 88-96. doi: https://doi.org/10.1016/j.jss.2006.10 .004 .

Bailey, J., Knight, A. and Balcombe, J. (2005) 'The future of teratology research is in vitro', Biogenic Amines, 19(2), pp. 97-145. doi: $10.1163 / 1569391053722755$.

Burow, M. E. et al. (2001) 'Phytochemical Gliceolins Isolated from Soy Medicine Antihormonal Effect Through Esterogen Receptor Alpha and Beta', The Journal of Clinical Endocrinology \& Metabolism, 86(4), pp. 1750-1758.

Busman, H. (2013) 'Histologi Ulas Vagina Dan Waktu Siklus Estrus Masa Subur Mencit Betina Setelah Pemberian Ekstrak Rimpang Rumput Teki', in Prosiding Semirata FMIPA Universitas Lampung.

Dalimarta, S. (2006) Atlas Tumbuhan Indonesia Jilid 4. Jakarta: Puspa Swara.

Dzulfikor, Y., Akbar and Susilo (2015) 'Uji Ekstrak Etanol Daun Pegagan (Centella asiatica L. Urban) Terhadap Fertilitas Tikus Putih (Rattus norvegicus) Betina pada Tahap Praimplantasi', Jurnal Biologi, 8(2), p. 102.

Egwuche, R. U., Odetola, A. A. and Erukainure, O. L. (2011) 'Prelimary Investigation into the Chemical Properties of Peperonia pellucida L', Research Journal of Phytochemistry, 5(1), pp. 48-53. doi: 10.3923/rjphyto.2011.48.53. 
Francis, G. et al. (2002) 'The biological action of saponins in animal systems: a review. Br J Nutr', The British Journal of Nutrition, 88(6), pp. 587-605. doi: 10.1079/BJN2002725.

Garor, R. et al. (2009) 'Effect of Basic Fibroblast Grotwh Factor on In Vitro Development of Human Ovarian Primordial Follicles', Fertility and Sterility, 91(5), pp. 1967-1975. doi: 10.1016/j.fertnstert.2008.04.075.

Goldstein, A., Aronow, L. and Kalman, S. M. (1974) Principles of Drug Action. 2nd edn. Edited by S. M. Kalman. New York: A Willey Biomedical Health Publication.

Harbinson, R. D. (1980) 'Casarett and Doull's Toxicology: The Basic Science of Poisons', in Casarett, L. J. and Doull, J. (eds) Teratogens. 2nd edn. New York: Macmillan Publishing Co. Inc., pp. 158-175.

Harbinson, R. D. (2001) 'Casarett and Doull's Toxicology: The Basic Science of Poisons', in Casarett, L. J. and Doull, J. (eds) Teratogens. 6th edn. New York: Macmillan Publishing Co. Inc.

Harlis, W. O., Malik, N. and Nufrianti (2018) 'Efektivitas Ekstrak Rimpang Jahe Putih (Zingiber officinale var. Amarum) Sebagai Antifertilitas Terhadap Kebuntingan Mencit (Mus musculus L.) Tahap Praimplantasi', Biowallacea, 15(1), pp. 761-772.

Kertia, N. et al. (2005) 'Pengaruh Pemberian Kombinasi Minyak Atsiri Temulawak Dan Ekstak Kunyit Dibandingkan Dengan Piroksikam Terhadap Angka Leukosit Cairan Sendi Penderita Dengan Osteoarthritis Lutut', Makalah Farmasi Indonesia, 6(3), pp. 155-161.

Limbong, T. (2003) Pengaruh Ekstrak
Etanol Kulit Batang Pakettu (Ficus superb Miq) Terhadap Folikulogenesis Ovarium Mencit (Mus musculus). Universitas Airlangga.

Lu, F. C. (1995) Toksikologi Dasar: Asas, Organ Sasaran, dan Penilaian Resiko. Edited by E. Nugroho, Z. S. B, and I. Darmansyah. Jakarta: Universitas Indonesia Press.

Majumder, P., Abraham, P. and V, S. (2011) 'Ethno-medicinal Phytochemical and Pharmacological review of an amazing medicinal herb Peperomia pellucida (L.) HBK.', Research Journal of Pharmaceutical, Biological and Chemical Sciences, 2(4).

Muna, L. (2010) Uji Teratogenik Ekstrak Pandanus conoideus Lam. Varietas Buah Kuning terhadap Perkembangan Embrio Tikus Putih (Rattus norvegicus). Universitas Sebelas Maret.

Rubiyati (2016) 'Pengaruh Pemberian Hidrokuinon Terhadap Perkembangan Fetus Mencit (Mus musculus L.) Swiss Webster', Jurnal Penelitian Sains, 18(1), pp. 34-40.

Santoso, H. B. (2006) Pengaruh Kafein terhadap Penampilan Reproduksi dan Perkembangan Skeleton Fetus Mencit (Mus musculus L.). Universitas Gadjah Mada.

Sheikh, H. et al. (2013) 'Hypoglycemic, Anti-inflammatory and Analgesic Activity of Peperomia pellucid (L.) HBK (Piperaceae)', International Journal of Pharmaceutical Sciences and Research, 4(1), pp. 458-463. doi: http://dx.doi.org/10.13040/IJPSR.09 75-8232.4(1).458-63.

Sumastuti, R. (2009) 'Pengaruh infus daun dan buah makuta dewa pada rahim marmot', Medika, 30(1), pp. 16-23. 
Wei, L. S. et al. (2011) 'Characterization of anticancer, antimicrobial, antioxidant properties and chemical compositions of Peperomia pellucida leaf extract', Acta Medica Iranica, 49(10), pp. 670-674.

Widyastuti, N. (2006) 'Efek Teratogenik

Ekstrak Buah Mahkota Dewa (Phaleria macrocarpa (Scheff.) Boel.) pada Tikus Putih (Rattus norvegicus L.) Galur Wistar', Bioteknologi, 3(2), pp. 56-62.

Wilson, J. G. (1973) Environment and
Birth Defects. New York: Academy Press.

Wink, M. (2008) 'Ecological Roles of Alkaloids', in Fattorusso, E. and Taglialatela-Scafati, O. (eds) Modern Alkaloids: Structure, Isolation Synthesis and Biology. Weinheim: Wiley-VCH Verlag $\mathrm{GmbH} \& \mathrm{Co}$. KGaA.

$\mathrm{Xu}, \quad$ S. et al. (2006) 'Bioactive compounds from Peperomia pellucida', Journal of Natural Products, 69(2), pp. 247-250. doi: $10.1021 / \mathrm{np} 050457 \mathrm{~s}$. 